\title{
O Significado Político da Produção Fonográfica Independente Brasileira
}

\author{
Leonardo De Marchi \\ Universidade Federal do Rio de Janeiro \\ leonardodemarchi@gmail.com
}

\begin{abstract}
Resumo: Neste texto, articula-se o significado político da produção fonográfica independente no Brasil, no final da década de 1970, ao contexto cultural e político dos anos 1960 e 1970. A hipótese é que tal conotação está intimamente ligada ao desenvolvimento do mercado de bens simbólicos no país e ao engajamento político da classe dos músicos no nacionalismo do pósguerra. O objetivo é demonstrar como o viés político emprestado à produção independente pode ser relacionado ao desenrolar desses processos.
\end{abstract}

Palavras-Chave: Política e Cultura no Brasil (1960-1970); Música Popular Brasileira; Indústria Fonográfica; Produção Independente.

\begin{abstract}
The aim of this paper is to articulate the political meaning suggested to the Brazilian independent production, at the end of the 1970, to the cultural and political context of the sixties and seventies. The hypothesis is that that connotation is closely related to the development of cultural market in Brazil and the political commitment of musicians to the post-war nationalism. In the following pages is demonstrated that the political character of independent record production can be understood as a result of these processes.
\end{abstract}

Key Words: Politics and Culture in Brazil (1960-1970); Brazilian Popular Music; Phonographic Industry; Independent Record Production.

Résumé: Dans cet texte, on rapporte le signification politique de la production phonographique indépendant en Brésil au bout de la décade de 1970, avec le contexte culturel et politique de la décade de 1960 et 1970. La hyphotése est que tel connotation était intimement attaché avec le dévelopment de la marché de biens symboliques dans le pays et avec le engagement politique de la classe des musicien dans le nationalisme de le

\footnotetext{
${ }^{1}$ Doutorando pelo Programa de Pós-Graduação da Escola de Comunicação da Universidade Federal do Rio de Janeiro.
} 
post-guerre. Le objectif est démontrer comme le biais politique rapporter a la production indépendant peut être raconter avec cette pròces.

Mots-Clés: Politique et Culture en Brasil (1960-1970); Musique Populaire Brésilien; Industrie Phonographique; Production Indépendante.

Resumen: En este texto, és articulado el significado político de la producción independiente de fonogramas en Brasil, al final de los 1970, a el contexto cultural y político de los años 1960 y 1970 . La hipótesis és que tal connotación está intimamente asociada a el desarrollo del mercado de bienes simbólicos en el país y a la asociación política de los músicos a el nacionalismo del posguerra. El objectivo és demonstrar como el cuño político prestado a la producción independiente és derivado del desarrollo de esos dos procesos.

Palabras Clave: Politica y Cultura en Brasil (1960-1970); Música Popular Brasileña; Industria de Fonogramas; Producción Independiente.

\section{Introdução}

No final da década de 1970, músicos brasileiros começaram a produzir discos com capital próprio, buscando alternativas ao controle do mercado nacional por gravadoras multinacionais. Ainda que musicalmente aqueles artistas não apresentassem semelhanças, havia uma comum crítica às chamadas 'grandes gravadoras', consideradas empresas 'estrangeiras' que pareciam intervir no processo de produção da música popular brasileira, mais preocupadas com o lucro do que com a excelência estética. Devido ao contexto da época, a inspiração nacionalista de tal atitude gerou especulações de que seria um ato político de contestação à situação da cultura no regime ditatorial. Ainda que os músicos envolvidos tivessem o cuidado de negar uma explicita motivação política, a produção 'independente’ acabou por ganhar um significado político que a acompanharia pelos anos seguintes. 
Neste texto, analisa-se o processo pelo qual a produção fonográfica independente recebeu tal significado político. A hipótese é que essa conotação sugerida àquela onda de produções de discos, algo que em si seria uma questão de mercado, está intimamente ligada a dois processos complementares. Por um lado, ao desenvolvimento do mercado de bens simbólicos no país, cujo crescimento e organização foram notáveis naquele período, o que acabou por contribuir de forma decisiva para a elevação da música popular a um outro patamar social. Por outro, a uma crescente conscientização política da classe dos músicos e seu engajamento no projeto político de uma cultura nacional e popular. Contrariando as narrativas sobre o período, nas quais política e mercado são descritas como instâncias excludentes, sustenta-se que o processo de 'politização' da música popular foi resultado da modificação de sua condição como mercadoria cultural a partir da estruturação das telecomunicações de massa, sobretudo, da televisão e da indústria fonográfica. $\mathrm{O}$ objetivo é demonstrar que, em um primeiro momento, a reformulação desses mercados foi fundamental para o deslocamento da música popular a um novo estatuto social e político. Em um segundo, os músicos envolvidos com o nacionalismo passaram a utilizar a comunicação de massas como veículo de propaganda ideológica. Todavia, por fim, na medida em que os golpistas militares passaram a intervir sistematicamente na cultura e a profissionalização do mercado de bens simbólicos tomou rumo distinto dos planos dos músicos nacionalistas é que se constituiu uma perspectiva crítica acerca da indústria fonográfica brasileira, fator determinante para a leitura da produção independente como expressão política.

O texto é dividido em duas partes. Na primeira, trata-se de articular a reorganização do mercado de bens simbólicos com o envolvimento de músicos com a vida política brasileira nos anos 1960. Para isso, subdivide-se essa seção em outras duas partes: uma que trata da Bossa Nova e o 'novo lugar social' (NAPOLITANO, 2001) da música popular e outra que revela a intima ligação entre a televisão comercial e a veia política da MPB. Na segunda, demonstra-se como, a partir de 1968, os cenários político, econômico e cultural brasileiros tomaram novos caminhos com a sistemática interferência dos militares sobre a cultura e as telecomunicações, a crescente corporativização do mercado de bens simbólicos e as desavenças na esquerda. Com isso, o mercado de música tomaria outra configuração, levando os 
músicos brasileiros à insatisfação e a produzir seus discos independentemente das grandes gravadoras. Com essa divisão, pretende-se sistematizar o complexo processo que possibilitou uma produção independente de discos no Brasil em final dos anos setenta, demonstrando sua dívida com a história do país naquele período.

\section{Pré-64: Reorganização do Mercado Fonográfico e a Politização da Música Popular}

Para compreender a sugestão de um ‘significado político’ dado à produção independente de fonogramas, no final dos anos 1970, é necessário reavaliar o processo pelo qual a música popular se tornou objeto de política ao longo dos anos anteriores. Isso exige atenção à reformulação de seu estatuto como mercadoria e expressão cultural.

O marco inicial é a Bossa Nova. Mesmo colocando em devida perspectiva a épica narrativa de ruptura e de modernização da música brasileira, celebrada por seus entusiastas, deve-se admitir que ela foi efetivamente norteadora da reorganização do mercado de música popular no Brasil no período posterior à Segunda Guerra Mundial e ao Estado-Novo. Como as inovações e débitos estilísticos dos bossa-novistas já foram bastante comentados por distintos autores, gostaria de me voltar para algo igualmente importante, porém pouco discutido: sua dimensão como produto e expressão artística.

No trabalho de Ruy Castro (1990), fica um pouco mais clara a maneira pela qual uma nova expressão musical se tornou um 'movimento' artístico de imenso impacto no mercado musical da época. Em sua detalhada narrativa, revela-se como os empresários musicais da época vislumbraram nas canções de influência cosmopolita (Jazz, sobretudo), no entanto, marcadamente influenciadas pelo samba e feitas por jovens compositores de classe média, uma mercadoria a ser identificada com o público jovem do pós-guerra, então, o principal consumidor da indústria fonográfica internacional, mas ainda pouco aproveitado no país. Uma vez tornada um produto, aquela música permitiria não apenas renovar os elencos e catálogos das gravadoras com os promissores músicos-compositores-arranjadores como também romper com a envelhecida audiência do samba-canção, disposta a gastar sua renda mais em outras formas de entretenimento do que em discos, substituindo-a pela 
juventude de classe média interessada no (e com possibilidades econômicas para o) consumo de bens culturais ${ }^{2}$.

Por isso, os agentes da empresa musical não tardaram em aproveitar a oportunidade. Buscaram sublinhar uma ruptura artística com o momento musical precedente também através da reformulação da música como produto. Note-se que foi com a Bossa Nova que o Long Play (LP) efetivou-se como elemento-chave dessa indústria, o que significava repensar o próprio suporte e revalorizar a reboque o conteúdo musical, algo de suma importância para a economia do mercado fonográfico ${ }^{3}$. Mesmo acatando o argumento de que a Bossa Nova não vendia significante quantidade de discos, é fato que possibilitou abarcar um importante público interno, a emergente classe média urbana, e externo, o mercado norteamericano, tornando-se o 'cartão de apresentação' da indústria musical brasileira (ou seja, assim como a música erudita, não é um produto que gera um retorno financeiro rápido e alto, porém é uma marca que concede prestígio cultural para a indústria, permitindo-a alcançar as classes sociais mais importantes economicamente). Com efeito, a injeção desses consumidores foi central para o mercado fonográfico nacional entrar, no início dos anos sessenta, numa fase de intensa expansão capitaneada pela 'nova' música popular.

A inclusão de uma classe economicamente importante e crescentemente intelectualizada no mercado fonográfico foi fundamental para o deslocamento da

\footnotetext{
${ }^{2}$ Lamento a ausência de trabalhos paradigmáticos sobre o mercado da música popular no Brasil ao longo dos anos 1940 e 1950. Pouco se sabe sobre sua história e sua economia. Todavia, pautando-me no que pesquisas de mercado desde o final da Segunda Guerra Mundial demonstram, na medida em que envelhece, o consumidor de bens culturais tende a gastar menos sua renda nesse tipo de produto. E se tomarmos a ênfase que o escritor Ruy Castro (1990) dá à idéia de que a 'juventude' era a principal motivação dos empresários musicais para venderem a Bossa Nova, está claro que o problema estava em renovar esse público consumidor de discos no Brasil.

3 Como argumentei em outro momento (2005), a adoção do Long Play como produto possibilitou uma substancial transformação na economia da indústria fonográfica. Como o novo meio continha mais músicas do que os antigos compactos de $78 \mathrm{rpm}$, as empresas passaram a escalonar as 'músicas de trabalho', aumentando o 'tempo de vida' do produto no mercado. Além disso, a promoção do novo meio foi desenvolvida no sentido de dar a ele um status de objeto estético em si e não mais um mero suporte para as músicas nele gravadas, algo refletido no cuidado que as próprias embalagens do produto passaram a ter - no caso da Bossa Nova, o trabalho gráfico realizado nas capas dos discos é notável. Esses fatores reunidos permitiram à indústria fonográfica trabalhar seus artistas em novos parâmetros de marketing, gerando retorno financeiro inédito em sua história.
} 
canção popular a um novo estatuto social. Ainda que a música popular fosse reconhecida como representação privilegiada da identidade nacional desde o Modernismo, a Bossa Nova simbolizava algo distinto: em meio ao momento desenvolvimentista, tornou-se uma importante expressão da 'nova' cultura brasileira, em que se almejava o equilíbrio entre o desejo de 'modernização', equivalente à 'progresso' econômico, e a valorização do 'nacional', equivalente a uma política independente das forças hegemônicas no contexto da Guerra Fria.

O propósito de 'modernizar' a música popular brasileira, misturando estilos cosmopolitas com o panteão do samba dos anos 1930, não se restringia a um desenvolvimento estilístico. De fato, operava uma importante resignificação do termo 'música popular'. Este não mais deveria ser entendido como 'folclore', conforme sugeriam os modernistas, tampouco como 'popularesco', como sugeriam o bolero e o samba-canção, mas uma arte. Sob a aparência de discussão formalista acerca dos audaciosos arranjos de Antônio Carlos Jobim e da qualidade literária das letraspoemas de Vinícius de Moraes, escondia-se um processo de submissão da música popular à apreciação estética e não mais ao estudo folclórico. Não por acaso, entusiastas iriam aproximar o emergente gênero musical às vanguardas modernistas para reclamar status de arte - nesse sentido, fica mais justo entender o rótulo de 'movimento', que objetivava menos definir com precisão o que foi aquela produção musical do que reafirmar a aproximação com as vanguardas artísticas. Abraçando tal desejo de 'modernização', a Bossa Nova deslocou a música popular brasileira para um 'novo lugar social', para utilizar a expressão de Marcos Napolitano (2001), significando uma legitimidade cultural e social desconhecida até então ${ }^{4}$.

Essa reformulação do estatuto da música popular permitiu a emergência de uma nova geração de músicos oriunda não de estratos mais baixos da classe média ou da popular, de onde a indústria fonográfica tradicionalmente recrutava funcionários, mas das mais abastadas, cujos jovens acabavam de ingressar no seleto grupo dos estudos superiores (universidade). Tinham, portanto, formação suficiente para compreender o tenso cenário político-econômico que caracterizava o período dos

\footnotetext{
4 Conforme a afirmação de Napolitano (ibidem), foi com a Bossa Nova que 'os estratos superiores das classes médias (...), mais abastados, mais informados e com circulação no meio universitário passaram a ver a música popular como um campo 'respeitável' de criação, expressão e comunicação'.
} 
anos 1950-60. De fato, a adoção da música popular como prática cultural legítima pela classe média foi relevante para colocar os novos compositores em contato com outros meios artísticos que possuíam viés político mais acentuado, como o teatro, as artes plásticas e a literatura. Esse intercâmbio foi decisivo para o que se pode chamar de 'conscientização política' da classe musical, isso é, o engajamento dos músicos em questões políticas, sobretudo, a defesa das causas nacionalistas 5 .

Nesse processo, um dos principais mediadores foi o Partido Comunista Brasileiro. Havia uma significativa adesão de artistas e intelectuais ao Partido desde o fim da Segunda Guerra, quando os comunistas se tornaram um dos principais heróis da resistência ao nazi-fascismo. Todavia, os contínuos desgastes resultantes de processos políticos internos (cassação do registro do Partido e repressão governamental aos comunistas) e da imposição da agenda zdanovista do realismo socialista geraram desgastes entre militantes e artistas filiados, deixando o partido um tanto isolado ao final dos anos cinqüenta, no plano cultural (como se deduz da exposição realizada por Denis de Moraes, 1997). Foi somente na esteira da revisão doutrinária do stalinismo, referendada com a Declaração de Março de 1958, que o PCB deu um importante passo para retomar seus diálogos político e cultural. Nesse documento, afirmava-se o caráter anti-imperialista e anti-feudal - ou seja, nacional e democrático - da revolução brasileira, que deveria ocorrer em duas etapas: primeiramente, com o desenvolvimento industrial capitalista de cunho nacionalista, o que supunha uma aliança com a burguesia 'progressista'; depois, a transição pacífica para o socialismo. Essa mudança levou o PCB a sair do isolamento político e a encontrar simpatia junto a outros setores nacionalistas.

Tal postura de diálogo também foi fundamental no âmbito cultural, restituindo a preponderância do PCB junto à classe artística. Com o declínio da

\footnotetext{
5 É fundamental lembrar que o termo 'nacionalismo' naquele contexto tinha um significado muito específico. Como César Guimarães (2001) apropriadamente explicou, os nacionalismos terceiro-mundistas que emergiram após a Segunda Guerra são caracterizados pelo projeto de uma soberania em termos político e econômico em relação aos interesses das duas potências da Guerra Fria, a União Soviética e os Estados Unidos. Como o Brasil estava nos limites da influência deste país, o nacionalismo contido no projeto desenvolvimentista foi entendido como situado à esquerda naquele espectro político (a direita liberal era tida, ainda que se considerasse nacionalista, como 'entreguista', pois sempre alinhada com os interesses dos EUA). Assim, o termo 'nacionalismo' significa, neste texto, uma orientação política à esquerda.
} 
diretriz zdanovista, a regulação ideológica se dissipou e se manteve uma posição de apoio a uma arte nacional e popular em que se denunciassem as condições de vida do povo brasileiro. A postura pragmática, não mais programática, de discussões e de tolerância estilística junto a artistas e intelectuais, que ou ingressaram ou se aproximaram do partido naquele período, ajudou a torná-lo um interlocutor central, de fato a referência ideológica, para a conotação política das expressões artísticas nacionalistas. Interessante notar que ao darem liberdade formal, os comunistas tenham encontrado uma nova geração de artistas que assumia a urgência de se engajar na 'defesa de uma arte nacional-popular, que colaborasse com a desalienação das consciências' (RINDENTI, 2000; p.91), objetivando a transformação (revolução) da sociedade brasileira.

Especificamente, significavam esses termos

no pré-64 (golpe militar), o nacional, correlato da luta antiimperialista, reinvidicava a afirmação de uma arte não-alienada que refletisse a realidade brasileira que se queria conhecer para transformar. O popular, por sua vez, acenava para a democratização da cultura e a conseqüente crítica à nossa tradição elitista de uma arte concebida como 'ornamento', como 'intimismo à sombra do poder'. (FREDERICO, 1998; p.277).

Esta citação condensa a agenda do ideal nacionalista na cultura. Conforme sintetiza Carlos Nelson Coutinho (2005), havia uma intenção de redimensionar a relação entre o 'povo' brasileiro e artistas, fazendo estes se engajarem no projeto de produzir uma arte em que se apresentasse àquele sua efetiva condição de vida (rompendo com a postura artística subjetiva e despreocupada com questões sociais, o 'intimismo à sombra do poder'), buscando colocá-lo 'adiante do duplo desafio de entender urgentemente o mundo em que vive (...) e de munir-se da vontade, dos valores, e dos sentimentos revolucionários (...) que o habilitem a romper os limites da presente situação material opressora', conforme afirmado no manifesto do CPC, assinado por Carlos Estevam (1962; s.p.). Essa busca pelo conhecimento da realidade brasileira para promover uma transformação social constituiria a motivação política e estética das distintas manifestações artísticas do período orientadas à esquerda, como as atividades promovidas pelo Centro Popular de Cultura da União Nacional dos Estudantes (CPC/UNE), os Teatros Opinião e Arena ou o Cinema Novo. 
Configurava-se, assim, o que viria a ser chamado de 'arte engajada' no projeto político de cultura nacional e popular.

No caso da música, o 'novo lugar social' possibilitou aos músicos nacionalistas se engajarem em projetos de 'conscientização' do povo através de canções - que na forma iam da sofisticação à Bossa Nova ao mimetismo de músicas regionais - que versassem acerca de sua condição. Tal preocupação foi motivadora das aproximações entre músicos, intelectuais e grupos artísticos à esquerda, como nos casos de Carlos Lira e o CPC, no disco 'O Povo Canta', de 1962; de Nara Leão e dramaturgos comunistas na montagem da peça 'Opinião', de 1964; ou no da parceria entre o dramaturgo e ator comunista Gianfrancesco Guarnieri e Edu Lobo, na canção 'Upa-Neguinho'; além de ser determinante na estética de compositores como Geraldo Vandré e Sérgio Ricardo. Assim, a música popular nacionalista assumia, definitiva e explicitamente, seu viés político.

Com o golpe de 1964 e subseqüente repressão da esquerda, o papel político da música popular foi potencializado. Devido às restrições de acesso às tradicionais formas de expressão política e a crescente preponderância da música nos meios de comunicação, sobretudo na TV, colocou-se para esses artistas uma nova situação, na qual pareciam ser o principal veículo de acesso da oposição às massas. Ao mesmo tempo dessa urgência de comunicação dos músicos nacionalistas, o empresariado envolvido com a organização da televisão no país percebia na renovada música popular uma ótima oportunidade para constituir audiência e alavancar suas emissoras. Foi na convergência desses interesses que se configuraria um novo 'movimento' musical e, naquela conjuntura, também político: a espetacular Música Popular Brasileira.

\section{4-1968: entre a Política e o Mercado, a Música Popular Brasileira}

Nos trabalhos sobre as artes populares dos anos 1960, sustenta-se que seu processo de politização se deu antes em uma esfera pública alheia ao mercado de bens simbólicos e quando, posteriormente, cooptadas por este, tiveram diluída sua força política contestadora (FREDERICO, 1998; ORTIZ, 1994; RIDENTI, 2000). Apesar da excelência dos argumentos - que seguem os princípios da crítica marxista 
da cultura, conforme empreendida por Lukács, Adorno e Frederic Jameson -, o caso da música popular revela que as relações entre política, arte e mercado eram mais complexas e interligadas naquela conjuntura do que se supõe. Ao se observar o caso da Música Popular Brasileira, torna-se difícil defender que ela não estivesse ligada desde seu início, através de fortes laços, com as instituições de um mercado de bens simbólicos. Com efeito, concordando com Marcos Napolitano (op.cit.), uma atenta análise da MPB revela com clareza que a constituição de seu viés político foi indissociável do desenvolvimento do mercado de telecomunicação, particularmente o televisivo.

Como o próprio Napolitano (op.cit.; p.57-59) observou, nos quatro primeiros anos do golpe, não se incidiu sobre a produção artística de forma sistemática - o que não significa que os militares não tenham desarticulado as ligações entre artistas, intelectuais e entidades, como a UNE, envolvidos com política e produção cultural; mas que os golpistas estiveram preocupados, em um primeiro momento, em repreender entidades como partidos e sindicatos. Aproveitando-se dessa 'condescendência' que precedeu a censura, os artistas engajados se viram diante da necessidade de resistência à ditadura. A conscientização das massas fazia-se urgente e as artes pareciam ser o principal veículo para esse fim, uma vez que as instituições propriamente políticas estavam sendo cassadas.

No caso da música popular, essa situação foi elevada a sua máxima potência devido ao trânsito que dispunha, como produto cultural, entre diferentes classes sociais. Essa potencialidade comunicativa se tornou ainda mais notável quando a emergente televisão comercial lançou mão dessa mesma popularidade para angariar audiência. Em suas lembranças sobre o período, Zuza Homem de Mello (2003) revelou o interesse dos empresários envolvidos com o novo meio de comunicação em utilizar a música como produto para cativar a classe média. Inspirados pelo sucesso do festival italiano de San Remo e pela renovação musical no país promovida pela Bossa Nova e pelo Rock n' Roll, os produtores executivos buscaram criar distintos programas de música. Assim, criou-se um programa para jovens interessados na voga do rock sessentista; outro para aqueles identificados com o projeto nacionalista; mais um para os que gostavam da 'velha-guarda' do Samba e do Choro; além de competições que atrairiam o público em geral, os Festivais da Canção. 
Por questão de contingência, tal segmentação foi simpática aos defensores da música nacional e popular, por definir sua identidade estética e política em oposição a um 'inimigo' comum. Colocado de um lado, estava o Rock feito por brasileiros, reunidos no programa Jovem Guarda, encarnando o 'intimismo à sombra do poder' a ser combatido. Do outro, os músicos nacionalistas, em O Fino da Bossa, crescentemente se identificando com uma 'autêntica' música popular nacional - algo ratificado com o re-batismo do programa para Frente Única da Música Popular Brasileira, em 1967, sublinhando o que era (e o mais importante, o que não era) parte dessa MPB. Os produtores dos programas viam na animosidade entre os músicos uma excepcional propaganda para a emissora. Pois ambos os shows, cujas estréias foram no ano de 1965, eram realizados pela mesma Rede Record, que promovia os Festivais da Canção mais concorridos da época - quanto mais ataques de Elis Regina a Roberto Carlos, mais atenção para a emissora. Naquela oportunidade, portanto, houve uma peculiar convergência entre os interesses do empresariado e da intelectualidade à esquerda. Isso não equivale a dizer que a MPB foi um produto manipulado pelo empresariado, mas que a estruturação da televisão comercial no país foi um elemento contingencial e fundamental na cristalização desse gênero musical. A televisão se tornava, em outras palavras, o espaço privilegiado de organização da empresa musical e do embate ideológico na música ${ }^{6}$.

Os programas que sintetizaram essa situação foram os Festivais da Canção. Contando com a participação de intelectuais simpáticos à causa nacionalista nas comissões julgadoras e com platéias formadas por jovens universitários comprometidos com a cultura nacional e popular, aquilo que passava a ser denominado de MPB efetivamente assumiu preponderância nessas competições, engendrando certo ciclo vicioso. A cada êxito dessas canções, criava-se a impressão de uma autêntica resposta do 'povo'. Conseqüentemente, crescia a expectativa na esquerda de usar a televisão e o mercado fonográfico como instrumentos de popularização da cultura nacional e popular. Dessa forma, a questão da 'tomada de consciência'

\footnotetext{
${ }^{6}$ Um evento representativo disso foi a apelidada 'Marcha contra as Guitarras' promovida pela Frente Única da MPB, em 1967. Ela foi tanto uma demonstração pública dos artistas engajados contra aquilo que consideravam influência imperialista na cultura brasileira quanto uma forma de propaganda pensada pelo empresário Paulo Machado de Carvalho, diretor da TV Record, para atrair atenção pública sobre o novo programa de MPB do canal.
} 
se firmava sobre um estatuto ambíguo: disseminar uma determinada ideologia nacionalista que pudesse ser assimilada por diversas classes sociais e realizar-se como produto de mercado, utilizando-se dos meios técnicos e organizacionais do mercado a sua disposição. Entende-se, a partir dessas expectativas, porque os festivais foram pontos de convergência entre os interesses do mercado e as tarefas ideológicas assumidas pelos músicos nacionalistas. Tratava-se de redefinir o popular, arrastando consigo a definição de nacional. (NAPOLITANO, 2001; p.93).

Isso significava que 'o mercado não era percebido como força determinante naquele processo' (ibidem; p.92), mas um importante instrumento. Enquanto o 'mercado' serviu aos interesses dos produtores televisivos e fonográficos - revelando compositores; popularizando intérpretes e canções; consolidando um público televisivo - e aos dos intelectuais e músicos engajados - expondo artistas; formando uma audiência comprometida com seus projetos, o que passava uma imagem de legitimidade popular - realmente não foi problema nem à estética nem à política. Entre 1964 e 1968, de fato, a MPB parecia ter atingido seus objetivos: tornara-se um produto valorizado e que difundia os princípios da cultura nacional e popular através da televisão.

No entanto, na virada da década, tal convergência começou a se desfazer. No plano político, as intervenções dos governos militares na cultura se tornariam sistematizadas. Sua contrapartida foi, à esquerda, o surgimento de dissidências que minaram o projeto político comum. No mercado, acentuou-se a 'corporativização' dos mercados de cultura e de telecomunicações, um processo que tomou um novo vulto em face das políticas governamentais. Enfim, os anos 1970 sugeriam um outro cenário político, cultural e econômico no país, no qual todos aqueles envolvidos com a produção de música popular teriam de rever suas posições.

\section{Pós-68: o Declínio do Nacional e Popular}

No final da década de sessenta, ficara evidente que o contexto do período anterior estava se desfazendo devido a alguns fatores. Um deles foi a investida sistemática dos militares sobre as telecomunicações e a cultura, considerados elementos estratégicos na consecução dos objetivos de 'integrar' o país com 'segurança' (ORTIZ, 1994). Tomem-se duas medidas exemplares nesse sentido. Com o Ato Institucional $\mathrm{n}^{0} 5$, de 1968, legalizava-se a face repressiva do regime, 
possibilitando aos militares varrer a oposição censurando, prendendo, torturando, exilando e mesmo assassinando quaisquer contestadores, inclusive artistas e intelectuais. Com a Política Nacional de Cultura, em 1974, formalizava-se uma etapa complementar, na qual o Estado conduziria o desenvolvimento do mercado de bens simbólicos segundo seus planos. Conforme Renato Ortiz demonstrou com riqueza de dados (op.cit.), o Estado passou a prover as condições infra-estruturais para o crescimento de todos os setores envolvidos com a telecomunicação e a cultura. Buscava-se configurar, assim, uma nova ordem de produção de cultura: reprimindo as associações políticas de esquerda, concedendo a produção de conteúdos à conservadora iniciativa privada e mantendo o Estado como 'elemento de apoio e estímulo à integração do desenvolvimento cultural dentro do processo global de desenvolvimento brasileiro' (PNC apud: HOLLANDA; GONÇALVES, 2005; p.111), isso é, como monitor desse processo.

A resposta foi, à esquerda, a fragmentação. Além da brutal violência de Estado sobre as organizações políticas, houve um profundo desencantamento com o PCB, algo que vinha desde 1964 e se tornou inconciliável com o recrudescimento do golpe em 19687, incentivando outras formas de atuar política - luta armada - e artisticamente. Neste caso, alguns artistas optaram pela radicalização do viés político de suas obras, sendo simpáticos à luta armada, se não participantes. Outros vislumbraram na estruturada comunicação de massas possibilidades de acessar um amplo público com suas idéias, sendo paradigmático a adesão dos dramaturgos à televisão (sobre os rumos da produção cultural dos comunistas após 1964 e, sobretudo, após 1968, ver FREDERICO, 1998; RIDENTI, 2000). O resultado disso foi, enfim, a gradual desintegração de um projeto coletivo da esquerda conforme aventado anteriormente, pois os sentidos dos termos 'nacional' e 'popular' na cultura passariam a serem interpretados de distintas formas por artistas e intelectuais.

No mercado de bens simbólicos, outro problema se punha aos artistas engajados. Se nos anos 1960 houve uma conciliação entre os interesses de artistas

\footnotetext{
7 As discordâncias no PCB vinham desde da declaração de Março de 1958, acentuando-se com a dissidência do PC do B, em 1962, e se tornando consideravelmente forte a partir de 1964, quando o 'Partidão' foi acusado de erro estratégico pelo 'etapismo' proposto em 1958. O recrudescimento do golpe de direita em 1968 apenas reforçou esse processo, engendrando alternativas às linhas política e cultural do PCB e a diminuição da força aglutinadora do partido na esquerda.
} 
nacionalistas e empresários do entretenimento, na década seguinte tal comunhão ficou estremecida. A desavença tinha inclusive um termo específico: 'profissionalização', eufemismo referente à crescente concentração da produção cultural em corporações.

Os anos 1970 marcaram a formação de grupos corporativos nacionais e a entrada de multinacionais nos setores de telecomunicação e de entretenimento. Sob o patrocínio dos governos militares, essas empresas passaram a investir altas somas na área cultural, por conseguinte, monopolizando os recursos de produção. Inicialmente, isso significou uma pungente expansão do mercado de bens simbólicos em âmbito nacional, sendo emblemático o caso da televisão. No da indústria fonográfica, por exemplo, esse foi um de seus períodos mais profícuos em termos de crescimento promovido pela reformulação da lei de direitos autorais e do sistema de arrecadação, pela Lei de Incentivo da Música Brasileira aprovada ainda em 1967, pelo Milagre Econômico e pela reestruturação do mercado junto a gravadoras multinacionais, que passariam a controlar sua dinâmica (AUTRAN, 2005; DIAS, 2000; NAPOLITANO, 2001; ORTIZ, 1994).

Tal crescimento capitaneado por poucas grandes empresas, no entanto, obrigou artistas e intelectuais à esquerda a reconsiderarem suas posições. Percebia-se que, naquele momento,

coloca(va)-se cada vez mais (acentuadamente) para o cinema, o teatro, as artes plásticas, a literatura etc. a necessidade de uma organização 'madura', empresarial, adequadas às condições de um capitalismo mais avançado, industrial, urbano, moderno, que, aos trancos e barrancos, v(inha) constituindo-se no país. (...). O caráter de mercadoria do produto cultural torna(ra)-se um dado cada vez mais presente, a exigir da intelectualidade a reelaboração de táticas para lidar com seu trabalho, com o mercado, com o capital. (HOLLANDA; GONÇALVES, 2005; p.112).

Esse acento da racionalidade empresarial colocava em perspectiva os ideais de 'popularização' do projeto nacional e popular através do mercado. Pois entre a censura estatal, as discordâncias na própria esquerda e as demandas comerciais das empresas, intelectuais e artistas engajados viam cada vez mais restritos seus espaços de atuação e fragmentada sua capacidade de comunicação. 
Essa percepção ficou evidente para aqueles envolvidos com a música popular. Com a contínua organização da empresa televisiva, a censura atuando sobre elementos-chave da MPB e certa saturação do formato dos programas, iniciou-se um movimento descendente dos Festivais da Canção (ver MELLO, 2003). Em pouco tempo, o processo de seleção das canções passou a ser coordenado, sobretudo, pelas empresas fonográficas em comum acordo com as emissoras. Isso significou uma relevante mudança de 'palco' de militância para os músicos engajados, pois

no contraditório movimento de afirmação da MPB, o equacionamento da tensão entre a diferenciação do 'popular' e a busca da 'popularização' (...) passaria por mecanismos mais complexos, cujo eixo principal se transferia (da televisão) para a indústria fonográfica, dominada pelas gravadoras multinacionais. (NAPOLITANO, 2001; p. 328).

Essa afirmação revela a impressão de que o 'mercado' passara de entidade 'neutra' à 'obstáculo' aos objetivos politicos. Ficara óbvio que tinham sido transformadas as condições objetivas que possibilitaram aos músicos engajados utilizarem a comunicação de massas. Seria necessário reavaliar as estratégias de ação política junto ao mercado de bens simbólicos - a expectativa de popularização de uma cultura nacional e popular declinara.

\section{A Produção 'Independente’ e seu Significado Político}

É nesse contexto que surgiria um descontentamento em relação à indústria fonográfica, especificamente, às práticas comerciais das gravadoras multinacionais. Ao longo dos anos 1970, multiplicaram-se críticas e acusações a essas empresas: deliberado aumento da produção e veiculação de músicas estrangeiras em detrimento das produções nacionais, visando a 'alienação' do povo ${ }^{8}$ (MÁRIO, 1986); uso indevido de benefícios fiscais, reservados à produção de música brasileira, para a produção de títulos estrangeiros ${ }^{9}$ (DIAS, 2000); colaboração das gravadoras com a censura estatal

\footnotetext{
8 É significativo reproduzir o seguinte parágrafo: 'essa 'marginalização' da música (popular brasileira) dentro do sistema montado parece estar dentro de um contexto maior de marginalização de todo o povo brasileiro. O 'sistema' estaria apoiado nas multinacionais, em grupos militares e civis. Isso poderia chegar a ponto de uma dissociação, onde teríamos dois poderes institucionalizados. Um poder seria o da grande massa marginalizada e o outro seria o representativo das forças dominantes' (MARIO, 1986; p.17).

9 Segundo afirmação de Dias (2000), as multinacionais utilizariam suas filiais no país para lançar títulos internacionais como se fossem produtos nacionais. Assim, a empresa multinacional não arcaria com grandes despesas, pois faria apenas a prensagem, embalagem e
} 
para a gerência da carreira dos $\operatorname{artistas}^{10}$ (AUTRAN, 2005). Com efeito, esses argumentos eram bastante razoáveis e não faltaram indícios de que atitudes suspeitas fossem praticadas por essas empresas. Todavia, não se pode afirmar que a produção de 'música brasileira' estivesse sendo prejudica. Na verdade, os dados oficiais do mercado revelavam que, naquela década, o Samba voltara a ser o mais lucrativo produto da indústria e que os discos de artistas estrangeiros não alcançaram sucesso comercial significativo a ponto de ameaçarem a produção dos nacionais, como demonstrou a jornalista Ana Maria Bahiana em um artigo de 1979 (2005). O que estava em jogo era, de fato, o rumo que o mercado tomara e o quanto isso afetou a o projeto de cultura nacional e popular. Claramente, a MPB perdera seu destaque como produto e conseqüentemente sua força ideológica agregadora, então diluída entre gêneros musicais embasados em outras perspectivas políticas. Em poucas palavras, havia sim muita música sendo produzida - deve-se lembrar que os anos 1970 foram um período de excepcional expansão do mercado fonográfico brasileiro - não necessariamente, porém, condizente com o projeto nacional-e-popular.

Mas algumas coisas devem ser esclarecidas. Muitos autores tendem a julgar o enfraquecimento da MPB, ou melhor, da cultura nacional e popular na música, como um feito exclusivo da 'modernização conservadora', promovida pelo Estado e encampada pela reacionária iniciativa privada. Não tenho dúvida de que isso é, em boa medida, correto. É inegável que o recorte político da MPB fez com que esses músicos sofressem restrições tanto da Censura estatal quanto das empresas que queriam alto retorno financeiro evitando problemas com os militares. As prisões, exílios e vetos às obras desses músicos foram fundamentais para diluir a união dos músicos engajados e o caráter político da canção popular, conforme adquirido nos anos anteriores. Todavia, não se pode esquecer que entre os próprios músicos nacionalistas houve uma profunda reavaliação de seus pressupostos estéticos e políticos. Desde o Tropicalismo, as idéias de que a adoção de uma estética ou de

distribuição local de matrizes gravadas no exterior. Além disso, esta prática aproveitaria, de forma indevida, as isenções da Lei de Benefício Fiscal, implementada a fim de ampliar a produção de discos (de músicas, de fato) nacionais.

${ }^{10}$ Conforme a jornalista Margarida Autran sugeriu, reproduzindo depoimentos de músicos ligados à MPB, 'as gravadoras, através de seus advogados, barganham com o Departamento de Censura, que confia a eles o poder de dizer quais as músicas 'graváveis' ou não' (2005; p.93). 
sonoridades estrangeiras minaria o caráter nacional da música popular ficaram descabidas. Aliás, os anos setenta foram pródigos nas misturas de música brasileira com ritmos e instrumentos internacionais, sobretudo, o Rock anglo-americano e a guitarra elétrica, gerando algumas das obras mais importantes da música popular praticada no país. Ao mesmo tempo a idéia de 'conscientização' do povo também foi reavaliada; ficou evidente que não bastavam canções para 'despertar' consciências e acabar com a ditadura. Mais do que isso, a nova geração de músicos profissionais que surgia se encontrava em um contexto político de crítica dos comunistas à linha cultural do PCB e, até mesmo, uma crítica mais geral ao próprio marxismo, sobretudo, por parte da contra-cultura. Dessa forma, quando se afirma que a coesão do projeto político de cultura nacional e popular se esvaía, não se pode considerar apenas as força repressoras do Estado ou do mercado. Um movimento interno também teve relevante participação nesse processo.

Assim, deve-se entender que era a forma de fazer política para a classe musical brasileira que passava por mudanças. Mesmo discordando ideologicamente, ficara patente para a classe artística que o ponto não era a estética apenas, mas a forma de produção de música no Brasil - e isso exigia um debate acerca da indústria fonográfica, então, o principal elemento na organização da empresa musical. $\mathrm{Na}$ medida em que ela estava sendo gerida em um sistema de monopólio de empresas multinacionais, muitos músicos passaram a atentar não mais para a música produzida, mas para seu modo de produção. Como o músico Marcus Vinícius apropriadamente observou à época,

não é a música estrangeira que nos (músicos brasileiros) ameaça e viola esteticamente. Quem nos ameaça realmente é o disco (grifo adicional), (...), que penetra no mercado com mil facilidades, que chega nas gravadoras (multinacionais) com o custo só de prensagem e que é despejado nos revendedores apoiado por intensa campanha publicitária feita e planejada no exterior. O problema é mercadológico e não estético (grifo adicional). Quem está ameaçada é a indústria musical brasileira ou, pelo menos, a produção de discos brasileiros. (apud: VAZ, 1988; p.19).

Esta citação revela a mudança de foco no debate. Se antes o mercado era tomado como mero veículo de propaganda ideológica, a partir daquele momento, passara a ser um elemento-chave para a música brasileira. Era preciso, portanto, que os músicos tomassem uma posição em relação o cenário monopolístico. Assim, não 
surpreende que, no final dos anos setenta, tenha havido uma contínua articulação entre os próprios músicos, que investiram seu capital na produção de discos e em suas apresentações, para criar alternativas às grandes gravadoras. Aproveitando-se do expressivo desenvolvimento do mercado interno, começaram a lançar discos sob a bandeira da produção independente. Conforme o rótulo sugere, o processo consistia em gravar as composições em estúdios alugados e mandar prensar um número reduzido de cópias para serem vendidas pelos próprios artistas em suas apresentações, sem qualquer intermediário.

E que fique claro que tal atitude não era mera opção profissional. Em um período em que se acenava à redemocratização política, a postura dos músicos de ter ingerência direta sobre sua produção estava, sim, investida de um significado político. É ponto pacífico que não havia uma proposta estética comum entre aqueles artistas, além de vários deles recusarem publicamente qualquer motivação política em seus atos, mas não se deve desconsiderar que o argumento de crítica às gravadoras multinacionais era um eco do nacionalismo dos anos anteriores. Crescentemente, a alternativa independente se tornava um ato político contestatório, pois democrático, no qual a soberania da música brasileira entrava em jogo. Nessa perspectiva, entendia-se que

o disco independente (...) consegui(ra) abrir uma brecha no monopólio das gravadoras multinacionais, mostrando a possibilidade de enfrentá-las. Isso cri(ara) uma nova realidade no mercado do disco onde a liberdade de criação tom(ara) o lugar da manipulação. Assim, temos um quadro diferente do conhecido até pouco tempo, com as gravadoras, sobretudo as nacionais, passando a trabalhar a serviço da cultura brasileira. Eis aí o significado político do disco independente (grifo adicional). (MÁRIO, 1986; p.16).

Aqui se resume o ponto, pois subordina tal veia política à questão nacional. A manipulação é instrumento de empresas 'estrangeiras' escoradas no Estado repressor; a produção nacional está 'a serviço da cultura brasileira', pois é independente desse sistema. Era isso que imprimia na produção independentebrasileira um sentido de ruptura com as regras do mercado e de desafio à situação política daquele momento. Em poucas palavras, a produção independente de discos tornou-se um ato político no sentido de simbolizar uma contestação à ditadura política e, no entendimento daqueles músicos, também à cultural. 


\section{Conclusão}

Infelizmente, a experiência daqueles músicos brasileiros de prescindir das estruturas das empresas multinacionais não durou muito tempo. Após alguns relativos sucessos comerciais, como no caso do grupo Boca-Livre e do coletivo da Lira Paulistana, o amadorismo das produções, a crescente profissionalização do mercado e as subseqüentes crises econômicas do país levaram à marginalização e, finalmente, ao ostracismo a produção independente nos anos oitenta (DE MARCHI, 2006). Todavia, a discussão gerada em torno das condições da produção fonográfica e, em última instância, da música popular no Brasil foi significativa para o meio musical.

Em primeiro lugar, porque constituiu uma visão crítica dos músicos sobre o mercado no qual estavam inseridos - algo que nunca havia atraído atenção, pois as principais discussões recaíam sobre a estética. Pela primeira vez, portanto, os músicos passaram a discutir como as instituições de seu mercado, sobretudo, as gravadoras multinacionais, interferiam ou não na produção de música e como isso prejudicaria ou não a música nacional. Conseqüentemente, questionava-se o papel das empresas na produção de cultura, concluindo-se daí a necessidade de uma indústria nacionalizada que fosse fiel às expressões culturais da nação. $\mathrm{E}$ foi essa a herança dos debates da década de sessenta. Pois a ligação entre gravadoras nacionais e a 'autenticidade' cultural não pode ser descontada de todo o debate político cerca do projeto de cultura nacional e popular - ainda que, de fato, este já estivesse em pleno declínio. Ou seja, a demanda de uma produção nacional de discos não pode ser apartada do ideal nacionalista que tomou conta das artes populares na década anterior.

E tal politização da questão fonográfica constituiria o mais importante legado dos músicos dos anos setenta. Ao final da década de 1990, em um contexto cultural, político e econômico absolutamente distinto, uma nova geração de músicos retomaria o projeto de uma indústria fonográfica nacionalizada, sob a bandeira de uma 'Nova Produção Independente', mais uma vez questionando as práticas comerciais de um mercado controlado por empresas de capital multinacional e reclamando uma indústria nacional comprometida com a 'autentica' cultura brasileira. 


\section{Referências}

AUTRAN, Margarida. O Estado e o Músico Popular: de Marginal a Instrumento. In:

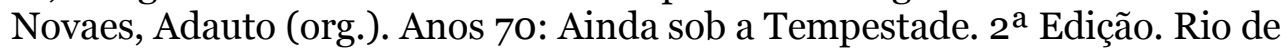
Janeiro: Ed. Aeroplano/ Ed. Senac Rio, 2005. p.87-93.

BAHIANA, Ana Maria. Importação e Assimilação: Rock, Soul, Discotheque. In:

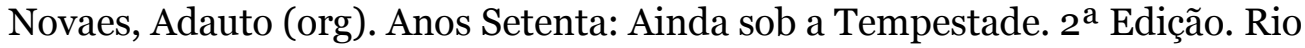
de Janeiro: Ed. Aeroplano/ Ed. Senac Rio, (1979) 2005. p.53-6o.

CASTRO, Ruy. Chega de Saudade: a História e as Histórias da Bossa Nova. São Paulo: Companhia das Letras, 1990.

COUTINHO, Carlos Nelson. Cultura e Sociedade no Brasil. Ensaios sobre Idéias e Formas. $3^{\mathrm{a}}$ edição. Rio de Janeiro: DP\&A, 2005.

DE MARCHI, Leonardo. A Angústia do Formato: uma História dos Formatos Fonográficos. In: E-Compós. Disponível em:<http://www.compos.org.br/ecompos/>. Acesso: abril de 2005.

. Do Marginal ao Empreendedor. Transformações no Conceito de Produção Fonográfica Independente no Brasil. Revista Eco-Pós. Rio de Janeiro: Ed. E-Papers, vol.9, nº 1, Janeiro-Julho, 2006. p.121-140.

DIAS, Márcia Tosta. Os Donos da Voz: Indústria Fonográfica Brasileira e Mundialização da Cultura. São Paulo: Boitempo, 2000.

ESTEVAM, Carlos. Por uma Arte Popular Revolucionária. In: Movimento, Revista da União Nacional dos Estudantes. Rio de Janeiro: Ed. Universitária, Maio de 1962.

FREDERICO, Celso. A Política Cultural dos Comunistas. In: Moraes, João Quartim de. História do Marxismo no Brasil, Volume III, Teorias/Interpretações. Campinas: Ed. da Universidade Estadual de Campinas, 1998. p. 275-304.

GORENDER, Jacob. Combate nas Trevas. A Esquerda Brasileira: das Ilusões Perdidas à Luta Armada. $4^{\mathrm{a}}$ Edição. São Paulo: Ed. Ática, 1990.

GUIMARÃES, César. Vargas e Kubitschek: a Longa Distância entre a Petrobrás e Brasília. In: Carvalho, Maria Alice Rezende de. República no Catete. Rio de Janeiro: Museu da República, 2001.

HOLLANDA, Heloisa Buarque de; GONÇALVES, Marcos Augusto. A Ficção da Realidade Brasileira. In: Novaes, Adauto (org). Anos Setenta: Ainda sob a Tempestade. $2^{\text {a }}$ Edição. Rio de Janeiro: Ed. Aeroplano/ Ed. Senac Rio, 2005. p.97-160.

MÁRIO, Francisco (Chico). Como Fazer um Disco Independente. Petrópolis: Ed. Vozes, 1986.

MELLO, Zuza Homem de. A Era dos Festivais: uma Parábola. São Paulo: Editora 34, 2003.

MORAES, Denis de. O Imaginário Vigiado: a Imprensa Comunista e o Realismo Socialista no Brasil (1947-53). Rio de janeiro: José Olympio, 1994. 
NAPOLITANO, Marcos. Seguindo a Canção: Engajamento Político e Indústria Cultural na MPB (1959-1969). São Paulo: Annablume/Fapesp, 2001.

ORTIZ, Renato. A Moderna Tradição Brasileira: Cultura Brasileira e Indústria Cultural. $5^{\text {a }}$ edição. São Paulo: Editora Brasiliense, 1994.

RIDENTI, Marcelo. Em Busca do Povo Brasileiro: Artistas da Revolução, do CPC à era da TV. Rio de Janeiro: Editora Record, 2000.

VAZ, Gil Nuno. História da Música Independente. São Paulo: Ed. Brasiliense, 1988. 